\title{
Formation of high molecular weight material by free-living marine bacteria
}

\author{
Andreas Heissenberger, Gerhard J. Herndl * \\ Dept. of Marine Biology, Institute of Zoology, University of Vienna, Althanstr. 14, A-1090 Vienna, Austria
}

\begin{abstract}
Bacterial transformation of leucine into high molecular weight dissolved organic matter (HMW-DOM) material was studied in seawater cultures. Three different types of cultures were used: sodium azide poisoned cultures served as control, eukaryotic inhibitors to prevent bacterivory, and untreated cultures were used to determine the effect of grazing on bacteria on the release of HMWDOM. All these cultures were labeled with ${ }^{14} \mathrm{C}$-leucine and the distribution of incorporated label into particulate organic matter (POM) and ${ }^{14} \mathrm{C}$ recovered in dissolved organic matter (DOM) was measured over a period of $10 \mathrm{~d}$ as well as the transformation into HMW-DOM. Fractionation of DOM was performed using dialysis membranes (molecular weight cutoff 50000 daltons) and by gel filtration for substances with a molecular weight below 1500 daltons. There was a shift to HMW-DOM discernible in grazed and ungrazed cultures and this DOM fraction accumulated to ca $6 \%$ of the initially added leucine in the grazed culture within $8 \mathrm{~d}$. Flagellates appeared to have only a minor influence on the formation of HMW-DOM but might be important in consuming bacterially derived HMW-DOM, representing a novel, nonpredatory way of carbon and energy transfer from bacteria to flagellates.
\end{abstract}

KEY WORDS: Extracellular release - Bacteria - Transformation - High molecular weight material Dissolved organic matter

\section{INTRODUCTION}

The largest pool of organic carbon in the sea is in a dissolved state comprising about 1000 gigatons or $97 \%$ of the total organic carbon in the oceanic water column (Ducklow \& Fasham 1992). This pool of dissolved organic carbon (DOC) is constantly fueled, mainly by the release of microorganisms. Phytoplankton especially contributes to this pool due to photosynthetic extracellular release. Phytoplankton releases DOC in all phases of growth: during exponential growth predominately low molecular weight material is released while during senescent stages high molecular weight substances are released into the surrounding water (Chróst \& Faust 1983). This release has been studied in detail during the last 2 decades (Fogg 1977, Sharp 1977, Bjørnsen 1988). There is a common consensus that this release forms the basis for the nutrition of bacterioplankton which in turn is preyed upon by

\footnotetext{
- Addressee for reprint requests
}

heterotrophic nanoflagellates. These flagellates rather than bacterioplankton provide inorganic nutrients for phytoplankton primary production. Thus a tight coupling exists between these 3 groups of microorganisms, cycling material and energy efficiently with only a comparatively small portion becoming available to higher trophic levels (Pomeroy \& Wiebe 1988). In this concept - the 'microbial loop' — bacteria are viewed as transformers of organic nutrients into living biomass and producers of carbon dioxide.

While the release of dissolved organic matter (DOM) by phytoplankton is well documented and considerable information is available on the release of DOM by flagellates, only little is known on the release of DOM by bacteria. Heterotrophic nanoflagellates have been shown to release dissolved free amino acids (Andersson et al. 1985, Taylor et al. 1985) as well as macromolecular compounds (Nagata \& Kirchman 1992). Natural communities containing grazers were shown to produce low molecular weight material (1000 daltons) from monomeric carbohydrates and free amino acids (Iturriaga \& Zsolnay 1981) over an incubation period of $3 \mathrm{~d}$. 
In a long-term experiment lasting over 6 mo Brophy \& Carlson (1989) determined the release of microbially derived DOM in the range 700 to 1400 daltons. These authors concluded that this material was mostly refractory in nature and only about $50 \%$ of the added tracer was respired within $6 \mathrm{mo}$

While the above-mentioned papers deal predominately with comparatively low molecular weight fractions of the released DOM, we do have evidence that a considerable portion of the bacteria-derived DOM is released as polymeric carbohydrates. In a recent review, Decho (1990) summarized the importance of slime capsules and biofilms surrounding bacterial cells for bacterial metabolism. Secretion of exopolymers by bacteria helps to maintain a stable environment for the bacteria and scavenge substances like charged organic nutrients and metal ions. These exopolymers also serve as a mechanism for attachment to surfaces (Vandevivere \& Kirchman 1993). Within this exopolymer layer ectoenzymes are embedded as well. These ectoenzymes may interact with DOM from the ambient water but are likely to solubilize bacteria-derived exopolymers as well. Recently, Tranvik (1993) showed that bacterial consortia are able to produce humic-like matter from glucose.

Since bacteria represent the largest biological surface in the ocean the role of DOM production by bacteria represents an important though unsolved problem. There is now growing evidence that bacteria not only take up DOM and produce biomass which is subsequently grazed, reflecting the classic 'microbial loop' concept, but also that they might actively shift the molecular weight distribution of the DOM pool in the ocean. In this study we investigated whether or not bacteria are able to produce high molecular weight (HMW) substances from free amino acids which are believed to play an important role in the nutrition of bacteria (Fuhrman \& Bell 1985, Sondergaard et al. 1985, Fuhrman \& Ferguson 1986). Furthermore, the influence of heterotrophic flagellates and bacterivory on production and release of HMW substances was determined. It is emphasized that bacterial transformation of easily metabolizable material into refractory substances might be an important process potentially influencing the capacity of the deep ocean to store DOC.

\section{MATERIAL AND METHODS}

Sampling and seawater culture conditions. Surface water samples (from $0.5 \mathrm{~m}$ depth) were taken with $\mathrm{HCl}$-rinsed Niskin bottles approximately 2 miles off Rovinj (Croatia) between September 1992 and May 1993. Seawater dilution cultures were done by inoculating $100 \mathrm{ml}$ of $0.8 \mu \mathrm{m}$ (Millipore, polycarbonate) filtered seawater into $900 \mathrm{ml}$ of $0.2 \mu \mathrm{m}$ (Millipore, polycarbonate) filtered seawater. The cultures were labeled with 10 to $50 \mathrm{nM}{ }^{14} \mathrm{C}$-leucine (specific activity $320 \mathrm{mCi}$ $\mathrm{mmol}^{-1}$ ) and kept at $20^{\circ} \mathrm{C}$ (nearly in situ temperature) in the dark. One culture poisoned with sodium azide (0.2\% final conc.) served as control. Eukaryotic inhibitors [colchicine (100 $\mathrm{mg} \mathrm{l}^{-1}$ ) and cycloheximide (200 $\left.\mathrm{mg} \mathrm{l}^{-1}\right)$ ] were used to prevent flagellate grazing on bacteria. Previous experiments using seawater cultures showed no effect of these inhibitors on bacterial growth over the first $100 \mathrm{~h}$ as determined by direct counting and by incorporation of ${ }^{3} \mathrm{H}$-thymidine as described in Sherr et al. (1986). After $100 \mathrm{~h}$ flagellate density increased in the untreated culture; concurrently, bacterial growth rates increased (Fig. 1). A third culture was left untreated to investigate the role of flagellate grazing on bacteria in the transformation of DOM. From these cultures, samples were taken for bacterial and flagellate density and for the analysis of DOM transformation at 12 to $48 \mathrm{~h}$ intervals. A total of 4 experiments were performed.

Incorporation and transformation of ${ }^{14} \mathrm{C}$-leucine. The amount of label incorporated into bacteria (particulate organic matter, POM) was determined by filtering $10 \mathrm{ml}$ of the culture onto a $0.45 \mu \mathrm{m}$ filter (Millipore $\mathrm{HA}, 25 \mathrm{~mm})$ and rinsing it with $5 \%(\mathrm{v} / \mathrm{v})$ ice-cold trichloroacetic acid. Subsequently, the filter was placed in a scintillation vial, dissolved in $1 \mathrm{ml}$ of ethylacetate and $7 \mathrm{ml}$ of scintillation cocktail (Insta-Gel, Packard) and the radioactivity assessed by a liquid scintillation counter (Tri-Carb, Packard). The filtrate was used to determine the radioactivity of the dissolved fraction. A $2 \mathrm{ml}$ volume of the filtrate was transferred into a scintillation vial and acidified with sulfuric acid to remove ${ }^{14} \mathrm{C}$-carbonates. Scintillation cocktail $(7 \mathrm{ml})$ was then added and the radioactivity determined.

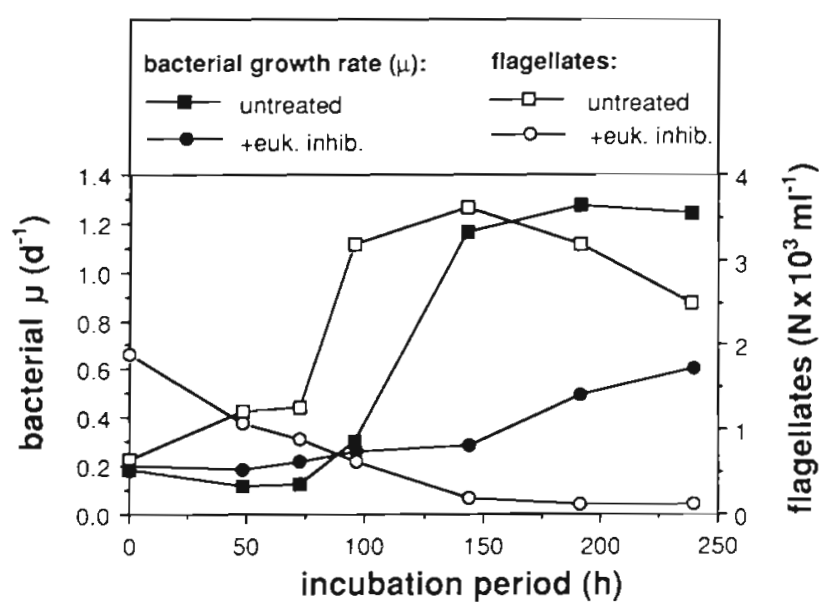

Fig. 1. Influence of a combination of eukaryotic inhibitors (colchicin and cycloheximide) on bacterial growth rates in seawater cultures over a $10 \mathrm{~d}$ incubation period 
Molecular weight distribution of transformed DOM. Dialysis: All glassware for the DOM analysis was precombusted at $450^{\circ} \mathrm{C}$ for $6 \mathrm{~h}$. DOM from the cultures was taken by gentle filtration $<200 \mathrm{mb}$ vacuum) through a $0.2 \mu \mathrm{m}$ filter (Millipore, polycarbonate). A $15 \mathrm{ml}$ volume of the DOM was transferred to a dialysis bag (Spectra/Por No. 7) with a molecular weight cutoff (MWCO) of 50000 daltons. Dialysis was performed in distilled water $(75 \mathrm{ml})$ for $24 \mathrm{~h}$ while gently shaking the flask. Previous tests had shown that after a period of $18 \mathrm{~h}$ equilibrium is reached (Heissenberger unpubl.). After $24 \mathrm{~h}$, the DOM confined in the bag was taken with sterile disposable polyethylene syringes and the radioactivity of this DOM fraction and the fraction outside the dialysis bag was determined after acidification by liquid scintillation counting as described above. Adsorption to the dialysis membrane or to the glass beaker in which dialysis was performed was less than $5 \%$.

Gel filtration: A total of $10 \mathrm{ml}$ of the original $0.2 \mu \mathrm{m}$ filtrate was freeze dried. The resulting powder was dissolved in $2 \mathrm{ml}$ of distilled water. This concentrating step was necessary to compensate at least partially for the subsequent dilution of the sample during gel filtration. Gel filtration was performed using a Sephadex G15 gel loaded to a $70 \times 2 \mathrm{~cm}$ column. A $1 \mathrm{ml}$ volume of the concentrated DOM was loaded to the column using a 4-way valve and a disposable syringe. Fractions of $2 \mathrm{ml}$ of the eluating buffer (borate buffer, $0.2 \%$ sodium azide, $\mathrm{pH} 8.5$ ) were collected using an automatic fraction collector (2211 Superrac, LKB). A total of $1 \mathrm{ml}$ of each fraction was taken to determine the radioactivity by liquid scintillation counting.

Amino acid analysis: Analysis was only carried out on DOM of the untreated cultures due to analytical problems caused by cycloheximide and sodium azide or their degradation products, respectively. Subsamples of the filtrate were transferred to precombusted glass ampoules and stored at $-20^{\circ} \mathrm{C}$ until analysis. Dissolved amino acids were measured by HPLC using the OPA-reversed phase method (Mopper \& Lindroth 1982). Samples for dissolved free amino acids (DFAA) were injected directly into the HPLC. Samples for dissolved combined amino acids (DCAA) were hydrolized under nitrogen for $22 \mathrm{~h}$ at $110^{\circ} \mathrm{C}$ using $6 \mathrm{~N} \mathrm{HCl}$ (final conc.). After hydrolysis the $\mathrm{HCl}$ was removed by evaporating the liquid at $5^{\circ} \mathrm{C}$ under vacuum (200 mtorr). The remaining powder was dissolved in an amount of HPLC-grade water (Merck) equivalent to the original sample volume. Complete dissolution of salt crystals was achieved by ultrasonication for $2 \mathrm{~min}$. After hydrolysis the sample was injected directly into the HPLC. Duplicate measurements were performed.
Bacterial and flagellate density. Bacterial density was determined on $5 \mathrm{ml}$ of formalin-fixed samples using the acridine orange direct counting method (Hobbie et al. 1977). Flagellates were enumerated using the same method but a $20 \mathrm{ml}$ sample volume. Biomass was calculated by applying a conversion factor of $20 \mathrm{fg} \mathrm{C}^{\mathrm{C}} \mathrm{cell}^{-1}$

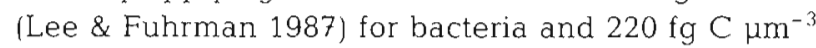
(Børsheim \& Bratbak 1987) for formalin-fixed heterotrophic flagellates.

\section{RESULTS}

The results shown here are from 1 typical experiment. They are, however, representative for the 3 other experiments. Slight differences are probably caused by community changes or alterations in the physiological condition of the organisms during the sampling period.

\section{Bacterial and flagellate density}

In the culture treated with eukaryotic inhibitors bacterial density reached $54 \times 10^{5}$ cells $\mathrm{ml}^{-1}$ after a period of $96 \mathrm{~h}$ and remained at that level throughout the experiment (Fig. 2). In the untreated culture bacterial density increased over a period of $48 \mathrm{~h}$. Thereafter flagellate density increased accompanied by a decline in bacterial abundance (Fig. 2). After $144 \mathrm{~h}$ flagellate biomass was about 4 -fold higher $\left(47.1 \mu \mathrm{g} \mathrm{C} \mathrm{l}^{-1}\right)$ than the bacterial biomass $\left(12.2 \mu \mathrm{g} \mathrm{C}^{-1}\right)$. In the sodium azide poisoned control no growth of bacteria or flagellates was observed (Fig. 2).

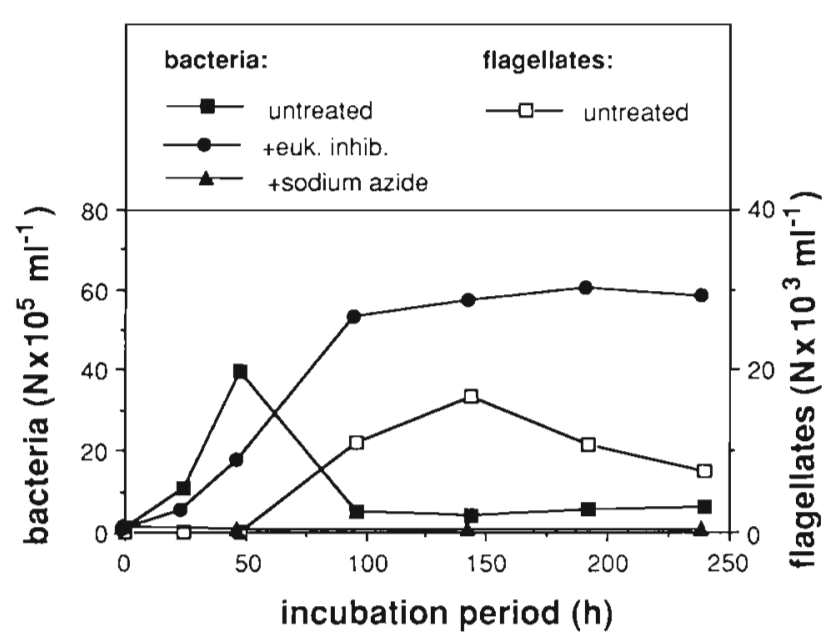

Fig. 2. Development of bacterial and flagellate density in untreated seawater cultures and in seawater cultures treated with eukaryotic inhibitors (euk. inhib.) or sodium azide 


\section{Incorporation and transiormation of ${ }^{14} \mathrm{C}$-leucine}

In all experiments there was a rapid uptake and incorporation of the labeled leucine within 48 h (Fig. 3). Thereafter a rapid release of labeled DOM in the untreated and therefore grazed cultures was detectable. Simultaneously the relative amount of ${ }^{14} \mathrm{C}$-POM decreased. In the ungrazed cultures (with eukaryotic inhibitors) the POM/DOM ratio did not change significantly over the incubation period (Fig. 3). Most of the labeled substrate, however, disappeared probably due to respiration. Within $10 \mathrm{~d}$ about $80 \%$ of the added tracer was lost in the grazed cultures and $70 \%$ in cultures where grazing was inhibited.

Although the POM/DOM ratio did not change over time the molecular weight (MW) distribution of the labeled DOM changed dramatically. Within $4 \mathrm{~d}$ the HMW fraction (>50000 daltons) became more important and dominated the DOM pool (activity $>50 \%$ of the total DOM activity; Fig. 4) for a short period of time. After $144 \mathrm{~h}$ the HMW fraction decreased again. In the control cultures no shift in the MW distribution in the DOM was detectable.

Gel filtration was used to determine the MW distribution below 1500 daltons. Within $24 \mathrm{~h}$ there was a noticeable shift to HMW substances (Fig. 5). After 96 h, when flagellate density increased and exerted probably high grazing pressure on bacteria, differences between the untreated and treated incubations became evident. In the flask containing high numbers of flagellates the MW distribution of the released ${ }^{14} \mathrm{C}$-labeled DOM was characterized by distinct peaks while the

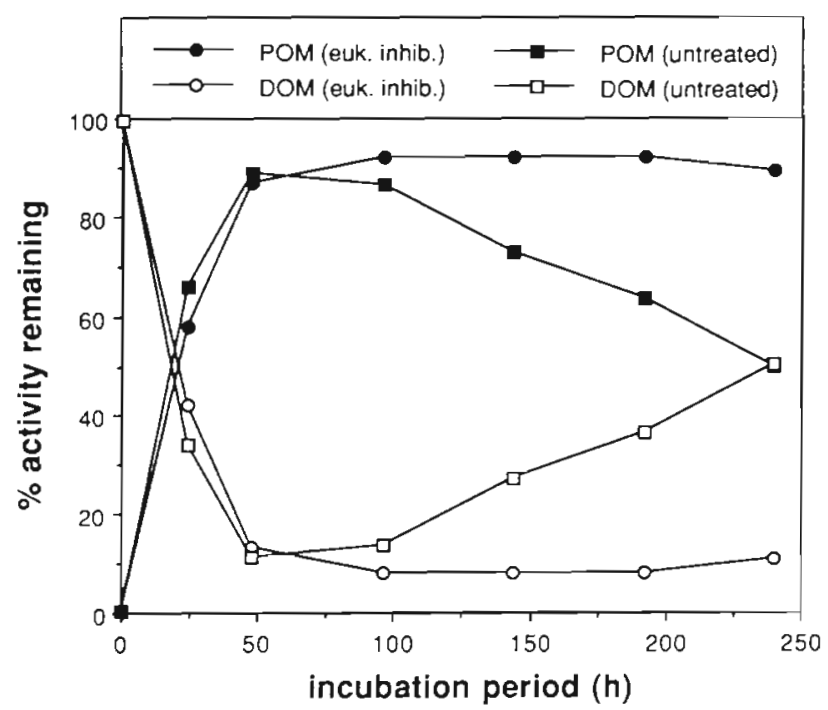

Fig. 3. Time course of the distribution of ${ }^{14} \mathrm{C}$ leucine added to seawater cultures. POM stands for the incorporated fraction and DOM represents the dissolved fraction. All values are calculated as percentage of the tracer remaining in the organic fraction. euk. inhib.: eukaryotic inhibitors

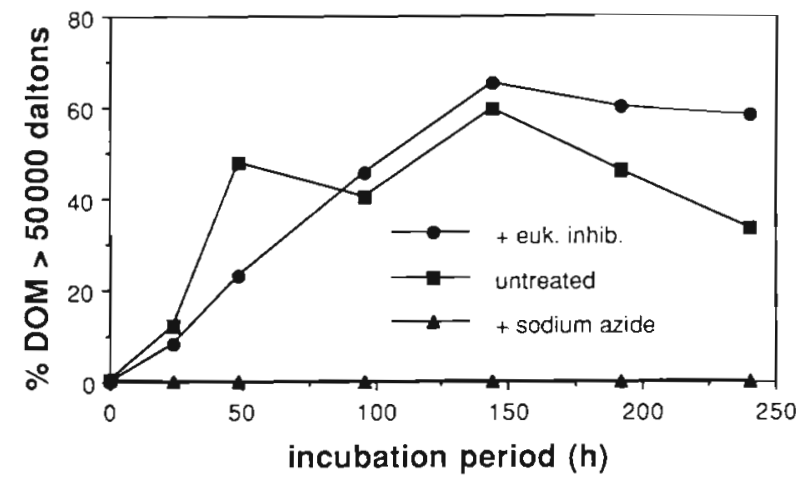

Fig. 4. Typical time course of the percentage of DOM of MW $>50000$ daltons as determined by dialysis membranes in an untreated seawater culture and seawater cultures treated with eukaryotic inhibitors (euk. inhib.) or sodium azide

MW distribution in the flask containing the eukaryotic inhibitors was more uniform. There was no change in the MW distribution in the sodium azide poisoned cultures.

\section{Amino acid analysis}

Amino acid analysis showed a continuous decrease in the concentration of DCAA and DFAA (Fig. 6). DFAA

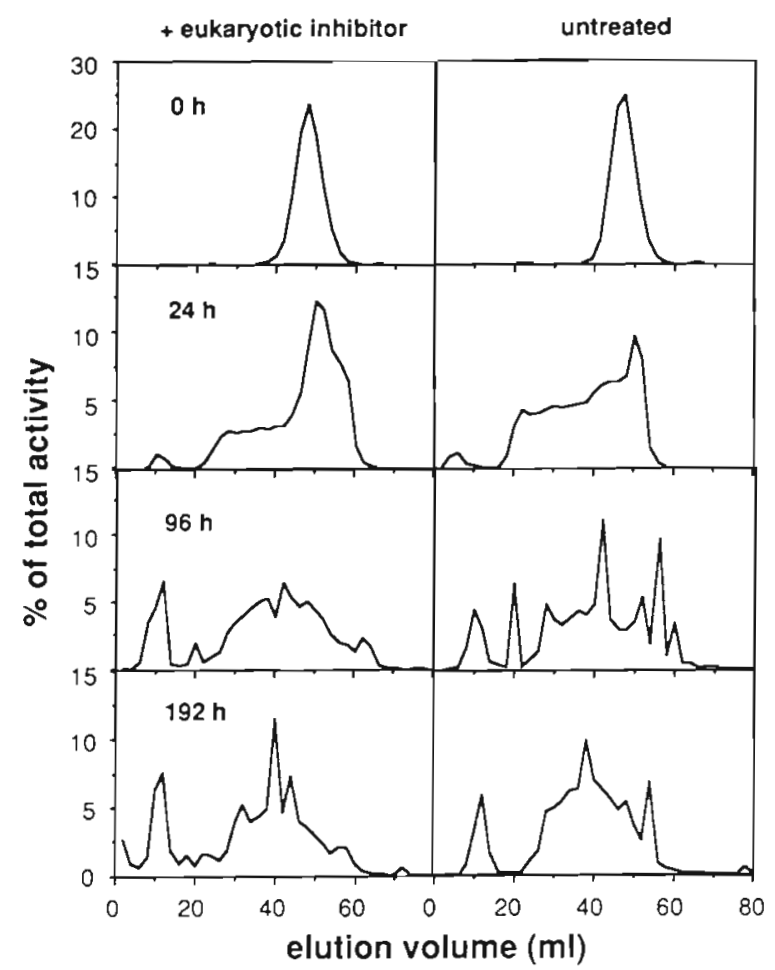

Fig. 5. MW distribution of DOM in an ungrazed bacterial culture (left panel) and a culture containing flagellates (right panel) as determined by gel filtration. Sampling times indicated in the left panel 


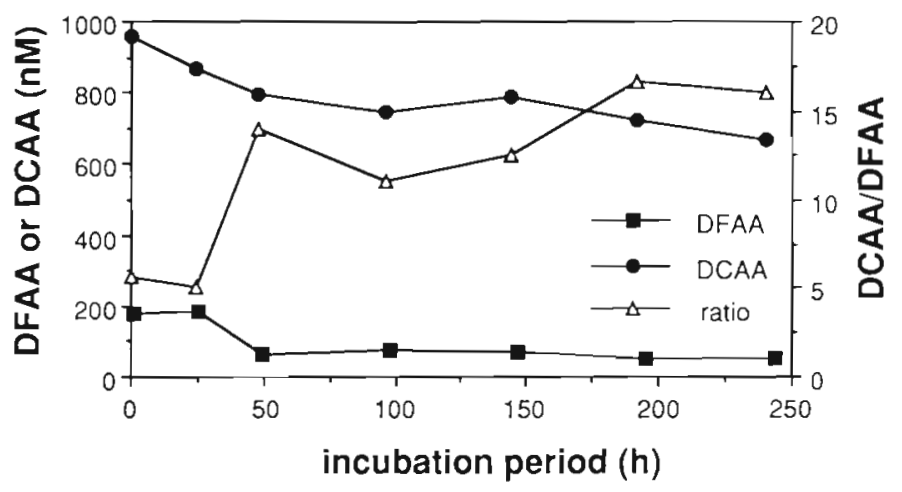

Fig. 6. Time course of dissolved free (DFAA) and combined (DCAA) amino acid concentrations in an untreated seawater culture. The ratio of DCAA/DFAA is also given

were taken up more rapidly than they were cleaved from the DCAA pool as indicated by the DCAA/DFAA ratio increase from 4 to 16 (Fig. 6),

\section{DISCUSSION}

All our experiments were done using seawater cultures with natural bacterial communities. This approach reflects natural nutrient availability at reduced grazing pressure. Seawater cultures have also been used frequently to determine conversion factors for radiolabeling techniques such as for thymidine and leucine incorporation to estimate cell and biomass production, respectively. Despite its wide use in experimental microbial ecology, little is known about the potential changes in the community structure occurring during incubation. Although nutrient concentrations are the same as in the natural environment, shifts in the community structure may occur due to the establishment of a more stable environment at reduced grazing pressure. Bacteria respond to this relief from grazing pressure exerted by heterotrophic nanoflagellates with an increase in cell size (Psenner \& Sommaruga 1992). Whether or not a shift in the species composition accompanies this change remains to be solved for seawater cultures. Despite these uncertainties we obtained only small variations between replicate seawater cultures and between seawater cultures of different sampling dates. Thus we are confident that the observed response of the inoculated bacterial consortia followed a predictable pattern comparable to the response of in situ bacterial communities.

With these seawater cultures we obtained typical growth curves for bacteria. Calculating the growth rate $(\mu)$ from the increase in bacterial density given in Fig. 2 we obtain a $\mu$ of $1.18 \mathrm{~d}^{-1}$ for the grazed culture and $0.67 \mathrm{~d}^{-1}$ for the ungrazed culture. The roughly twice as high growth rate in the grazed culture might indicate that grazing by flagellates keeps the bacterial community in a more juvenile, active stage. The growth rates we determined are within the range obtained with radiolabeling techniques (thymidine and leucine incorporation); thus we have evidence that our experimental approach did not create unrealistic conditions for bacterial growth.

As shown in Fig. 3, leucine was taken up efficiently within $48 \mathrm{~h}$ in both the culture with and without the eukaryotic inhibitor despite the fact that $80 \%$ of the added tracer disappeared within $10 \mathrm{~d}$. Flagellate grazing on bacteria (as indicated in Fig. 2) is likely to be responsible for the decreasing fraction of radiolabeled organic matter detectable in the POM fraction of the untreated culture while the percentage of the radiolabeled DOM pool increases. This indicates that heterotrophic flagellates release a part of the ingested radiolabeled bacterial prey in the form of DOM. Similar findings have been reported by Taylor et al. (1985) and Nagata \& Kirchman $(1991,1992)$. The ecological significance of flagellate-derived release of DOM will be discussed later in this paper. The percentage of DOM higher than 50000 daltons increased during the course of incubation (Fig. 4). While in the culture in which bacterivory was inhibited the HMW fraction reached a maximum of about $60 \%$ of the total radiolabeled DOM after $150 \mathrm{~h}$ and remained at this level throughout the incubation, the HMW fraction in the culture in which flagellates were present declined, probably reflecting uptake of this HMW material by flagellates as shown by Sherr (1988) and Tranvik et al. (1993). Although bacterial biomass declined rapidly in the flask containing flagellates the percentage of HMW material released did not change. Furthermore the percentage of released HMW material remained almost constant for the last $100 \mathrm{~h}$ of incubation (Fig. 4); one might tentatively expect that a higher percentage of HMW material is released during the senescent stage of bacteria especially in the absence of grazing. As demonstrated in Figs. 4 \& 5, leucine is transformed into HMW fractions within $2 \mathrm{~d}$ and within $4 \mathrm{~d}$ DOM with a molecular weight higher than 50000 daltons is formed. Based on our gel filtration results the influence of flagellates on the MW distribution seems negligible. Obviously, HMW fractions are formed without a significant influence of flagellates as shown in Fig. 5. Whether or not viruses contributed significantly to the HMW fraction remains unknown. Peduzzi \& Weinbauer (1993), however, detected an increase in viruslike particles concurrently with an increase in bacterial density.

Separating DOM of different MW by dialysis requires that the dialysis time be kept as short as possible 
to prevent bacteria from growth and taking up fractionated DOM and as long as necessary to achieve equilibrium between inside and outside the bag. A major drawback when using gel filtration is the lack of suitable markers, making it impossible to determine the actual MW distribution; however, gel filtration is extremely sensitive at the lower end of the MW spectrum, enabling us for example to distinguish leucine (130 daltons) from glucose (180 daltons). Despite these methodological limitations we were able to show clearly that natural bacterial consortia release HMWDOM within a relatively short period of time. We do have evidence that the observed pattern reflects microbial transformation as sodium azide treated waters did not show any indication of abiotic formation of HMW-DOM. This is in contrast to findings of Jensen \& Søndergaard (1982) who found abiotic particle formation from phytoplankton extracellular release which might be caused by coagulation of HMW material; an additional mechanism leading to particle formation is 'bubble scavenging' of DOM on rising gas bubbles in the surface layers of the turbulent ocean (Kepkay 1990, Kepkay \& Wells 1992). Since we added low MW material (leucine) to our cultures under nonturbulent conditions we are confident that all the observed transformation of leucine into HMW material is mediated by the microbial community.

As shown in Fig. $7 a$, about $6 \%$ of the initial leucine concentration accumulated as MW material $>50000$ daltons within $8 \mathrm{~d}$. This accumulation of HMW-DOM suggested that the percentage of the actual leucine concentration transformed into this HMW-DOM fraction is even higher since it is reasonable to assume that a part of this transformed leucine is cleaved by bacterial extracellular enzymes into low molecular weight material (LMW-DOM) again during the $10 \mathrm{~d}$ of the incubation period. If we now assume that the accumulation rate measured (Fig. $7 a$ ) is the actual transformation rate, thus assuming no concurrent cleavage of this material, we are able to evaluate the role of marine free-living bacteria in the conversion of DFAA into HMW-DOM in the ocean. Assuming a mean leucine concentration of $10 \mathrm{nM}$ in the surface waters of the ocean and a total DFAA concentration of $200 \mathrm{nM}$ (Mopper \& Lindroth 1982, Fuhrman \& Ferguson 1986, Fuhrman 1987) and comparing these concentrations with the transformation rate obtained from Fig. $7 \mathrm{a}$ of $0.04 \mathrm{nmol}$ leucine $\mathrm{l}^{-1} \mathrm{~d}^{-1}$, or $0.8 \mathrm{nmol}$ DFAA $1^{-1} \mathrm{~d}^{-1}$ (assuming equal transformation rates for all DFAA as for leucine), we arrive at a transformation time (ambient conc./tranformation rate) of leucine into HMW-DOM $>50000$ daltons of $250 \mathrm{~d}$. This is considerably higher than the calculated protein (bovine serum albumin) turnover of $8 \mathrm{~d}$ (Hollibaugh \& Azam 1983) or the DOC turnover under phytoplankton bloom conditions of 10 to $40 \mathrm{~d}$ (Kirchman et al. 1991).

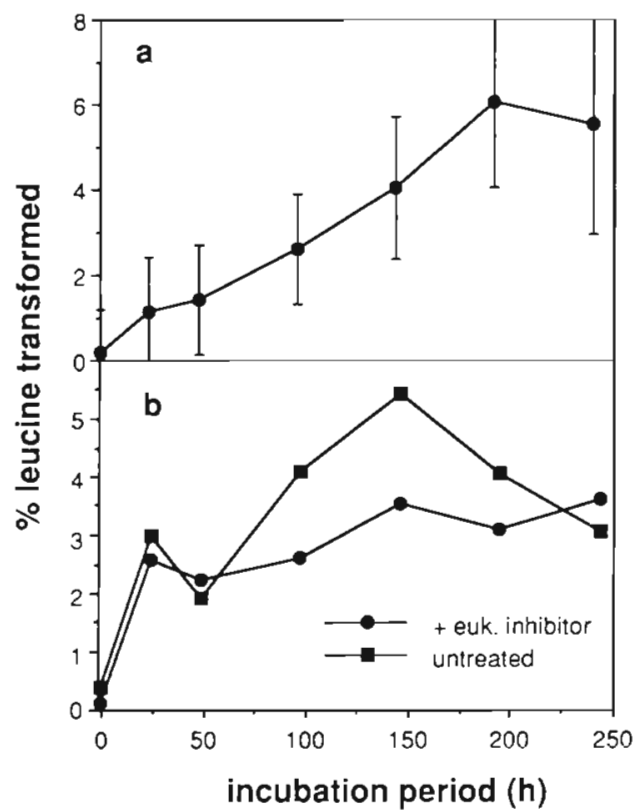

Fig. 7. (a) Mean accumulation ( \pm SD) in all 4 untreated seawater cultures. (b) Time course of the accumulation of transformed leucine into the HMW-DOM fraction (>50000 daltons) in an untreated culture and in a culture where flagellate growth was inhibited

Both the protein and the DOC turnover time are considerably lower than our transformation time from LMWDOM into HMW-DOM, however, both bovine serum albumin and DOC under phytoplankton bloom conditions might be expected to be easily degradable by microbes while the transformed leucine in our study can be regarded as refractory material for bacteria. Two lines of evidence support this: firstly, the transformed material accumulated over a period of $10 \mathrm{~d}$ and secondly, Tranvik (1993) recently showed that ca $3 \%$ of the initially added glucose was tranformed to humic-like DOM after $1 \mathrm{wk}$. The agreement between the findings of Tranvik (1993) and our results is striking considering the different metabolic fate of glucose and leucine in bacteria.

Transformation of leucine in the untreated control (with flagellates included) indicates a slightly higher production of DOM $>50000$ daltons than in the bacterial cultures and a subsequent utilization of this HMW-DOM in the late stage of the culture (Fig. 7b) probably by flagellates as has been reported by Sherr (1988) and Tranvik et al. (1993). Thus utilization of bacterially derived HMW-DOM by flagellates may be an alternative, nonpredatory route of transfer of carbon and energy from bacteria to flagellates.

In summary, we have shown that marine bacterioplankton produces substantial amounts of HMW-DOM which resists degradation. Therefore, the path of DOM through bacteria is not only characterized by extracel- 
lular enzymatic cleavage of DOM into easily assimilable LMW-DOM which is taken up efficiently (Azam \& Cho 1987 ) but bacteria also produce refractory HMWDOM. Thus bacteria may play an important role in structuring the molecular weight distribution of DOM in the sea. Based on our findings, we tentatively assume that the molecular weight distribution of DOM in the ocean is influenced by the bacterial release of refractory HMW-DOM.

Acknowledgements. We thank the staff of the Center for Marine Research at Rovinj (Croatia) and our colleagues for invaluable help and discussions on this subject. The manuscript was improved by the comments of J. A. Ott and 3 anonymous reviewers. Financial support was provided by a grant from the Austrian Science Foundation (FWF grant \# 8608) to G.J.H. This work is in partial fulfillment of the requirements for a M.Sc. degree from the University of Vienna by A.H.

\section{LITERATURE CITED}

Andersson, A., Lee, C., Azam, F., Hagström, §̊. (1985). Release of amino acids and inorganic nutrients by heterotrophic marine microflagellates. Mar. Ecol. Prog. Ser. 23: 99-106

Azam, F., Cho, B. C. (1987). Bacterial utilization of organic matter in the sea. In: Society of General Microbiology (eds.) Ecology of microbial communities. Cambridge University Press, Cambridge, p. 261-281

Bjørnsen, P. K. (1988). Phytoplankton exudation of organic matter: why do healthy cells do it? Limnol. Oceanogr. 33: $151-154$

Borsheim, K. Y., Bratbak, G. (1987). Cell volume to cell carbon conversion factors for a bacterivorous Monas sp. enriched from seawater. Mar. Ecol. Prog. Ser. 36: 171-175

Brophy, J. E., Carlson, D. J. (1989). Production of biologically refractory dissolved organic carbon by natural seawater microbial populations. Deep Sea Res. 36: 497-507

Chróst, R. H., Faust, M. A. (1983). Organic carbon release by phytoplankton: its composition and utilization by bacterioplankton. J. Plankton Res. 5: 477-493

Decho, A. W. (1990). Microbial exopolymers secretions in ocean environments: their role(s) in food webs and marine processes. Oceanogr. mar. Biol. A. Rev. 28: 73-153

Ducklow, H. W., Fasham, M. J. R. (1992). Bacteria in the greenhouse: modeling the role of oceanic plankton in the global carbon cycle. In: Mitchell, R. (ed.) Environmental microbiology. Wiley-Liss, New York, p. 1-32

Fogg, G. E. (1977). Excretion of organic matter by phytoplankton. Limnol. Oceanogr. 22: 576-577

Fuhrman, J. (1987). Close coupling between release and uptake of dissolved free amino acids in seawater studied by an isotope dilution approach. Mar. Ecol. Prog. Ser. 37: 45-52

Fuhrman, J. A., Bell, T. M. (1985). Biological considerations in the measurement of dissolved free amino acids in seawater and implications for chemical and microbiological studies. Mar. Ecol. Prog. Ser. 25: 13-21

Fuhrman, J. A., Ferguson, R. L. (1986). Nanomolar concentrations and rapid turnover of dissolved free amino acids in seawater: agreement between chemical and microbiological measurements. Mar. Ecol. Prog. Ser. 33: 237-242

Hobbie, J. E., Daley, R. J., Jasper, S. (1977). Use of Nuclepore filters for counting bacteria by epifluorescence micro- scopy. Appl. environ. Microbiol. 33: 1225-1228

Hollibaugh, J. T., Azam, F. (1983). Microbial degradation of dissolved proteins in seawater. Limnol. Oceanogr 28: $1104-1116$

Iturriaga, R., Zsolnay, A. (1981). Transformation of some dissolved organic compounds by a natural heterotrophic population. Mar. Biol. 62: 125-129

Jensen, L. M. Sondergaard, M. (1982). Abiotic formation of particles from extracellular organic carbon released by phytoplankton. Microb. Ecol. 8: 47-54

Kepkay, P. E. (1990). Surface coagulation and microbial respiration in response to local advection and sea state in the North Atlantic. Mar. Ecol. Prog. Ser. 69: 143-147

Kepkay, P. E., Wells, M. L. (1992). Dissolved organic carbon in North Atlantic surface waters. Mar. Ecol Prog. Ser. 80 $275-283$

Kirchman, D. L., Suzuki, Y., Garside, C., Ducklow, H. W. (1991). High turnover rates of dissolved organic carbon during a spring phytoplankton bloom. Nature 352: 612-614

Lee, S., Fuhrman, J. A. (1987). Relationships between biovolume and biomass of naturally derived marine bacterioplankton. Appl. environ. Microbiol. 53: 1298-1303

Mopper, K., Lindroth, P. (1982). Diel and depth variations in dissolved free amino acids and ammonium in the Baltic Sea determined by shipboard HPLC analysis. Limnol. Oceanogr. 27: 336-347

Nagata, T., Kirchman, D. L. (1991). Release of dissolved free and combined amino acids by bacterivorous marine flagellates. Limnol Oceanogr. 36: 433-443

Nagata, T., Kirchman, D. L. (1992), Release of macromolecular organic complexes by heterotrophic marine flagellates. Mar. Ecol. Prog. Ser. 83: 233-240

Peduzzi, P., Weinbauer, M. G. (1993). The submicron size fraction of seawater containing high numbers of virus particles as bioactive agent in unicellular plankton community successions. J. Plankton Res. 15: 1375-1386

Pomeroy, L. R., Wiebe, W. J. (1988). Energetics of microbial food webs. Hydrobiologia 159: 7-18

Psenner, R., Sommaruga, R. (1992). Are rapid changes in bacterial biomass caused by shifts from top-down to bottom-up control? Limnol. Oceanogr. 37: 1092-1100

Sharp, J. H. (1977). Excretion of organic matter by phytoplankton: do healthy cells do it? Limnol. Oceanogr. 22: 381-399

Sherr, B. F., Sherr, E. B., Andrew, T. L., Fallon, R. D., Newell S. Y (1986). Trophic interactions between heterotrophic Protozoa and bacterioplankton in estuarine water analyzed with metabolic inhibitors. Mar. Ecol. Prog. Ser. 32: 169-179

Sherr, E. B. (1988). Direct use of high molecular weight polysaccharide by heterotrophic flagellates. Nature 335: $348-351$

Søndergaard, M., Riemann, B., Jørgensen, N. (1985). Extracellular organic carbon (EOC) released by phytoplankton and bacterial production. Oikos 45: 323-332

Taylor, G. T., Iturriaga, R., Sullivan, C. W. (1985). Interactions of bacterivorous grazers and heterotrophic bacteria with dissolved organic matter. Mar. Ecol. Prog. Ser. 23: 129-141

Tranvik, L. J. (1993). Microbial transformation of labile dissolved organic matter into humic-like matter in seawater. FEMS Microbiol. Ecol. 12: 177-183

Tranvik, L. J., Sherr, E. B., Sherr, B. F. (1993). Uptake and utilization of 'colloidal DOM' by heterotrophic flagellates in seawater. Mar. Ecol. Prog. Ser. 92: 301-309

Vandevivere, P., Kirchman, D. L. (1993). Attachment stimulates exopolysaccharide synthesis by a bacterium. Appl. environ. Microbiol 59: 3280-3286

Manuscript first received: November 1, 1993

Revised version accepted: May 31, 1994 